\title{
Monitoreo de arroz, soya y maíz comercializados en Nicaragua para detección de material transgénico
}

\author{
Julio A. Gómez-Rodríguez ${ }^{1}$, Noëllie Oudet ${ }^{2}$ y Jorge A. Huete-Pérez ${ }^{1}$ \\ ${ }^{1}$ Centro de Biología Molecular (CBM). Facultad de Ciencia, Tecnología y Ambiente. Universidad Centroamericana, Rotonda Rubén Darío, \\ 500mts al oeste, Apto. Postal 69. Managua, Nicaragua. Tel: 278-3923 Ext. 1189. E-mail: juliogomer@gmail.com \\ ${ }^{2}$ Institut des Sciences et Industries du Vivant et de l’Environment, Francia.
}

Recibido: noviembre de 2007 / Aceptado: noviembre de 2007

EL CULTIVO DE ORGANISMOS GENÉTICAMENTE MODIFICADOS -conocidos como transgénicosha ido en aumento desde su aprobación comercial en 1994. Nicaragua no tiene restricciones de importación de estas semillas y alimentos. Sin embargo, dado el intercambio comercial con países productores de transgénicos, se ha especulado que no se han respetado las normas de importación establecidas. El Centro de Biología Molecular de la UCA, a través de un muestreo al azar, se propuso investigar la presencia de material transgénico en arroz, soya y maíz importado y disponible en los principales puestos de venta del país. Analizamos las muestras mediante dos métodos comúnmente usados en laboratorios de diagnóstico molecular: pruebas inmunológicas y detección a nivel de ADN del promotor 35S y el terminador NOS. Aquí presentamos los resultados del trabajo y reportamos que en el período comprendido en este estudio no se detectaron semillas transgénicas en Nicaragua.

Palabras clave: biotecnología vegetal / pruebas clínicas / alimentos transgénicos / Nicaragua

\section{Introducción}

La biotecnología moderna, y en particular, las técnicas de ingeniería genética aplicadas al sector agroalimentario, han permitido la creación de plantas y alimentos denominados organismos genéticamentemodificados (OGM) y conocidos comúnmentecomo “transgénicos". Desde los primeros cultivos transgénicos en 1994, el área sembrada con cultivos transgénicos ha ido aumentando notablemente en los últimos años. Según estudios publicados en 2007 (James, 2007), el crecimiento durante el período 1996-2006 correspondió a un aumento sin precedentes de 60 veces. Por otra parte, el número de productores que cultivan transgénicos experimentó también un aumento, alcanzando los 10.3 millones de agricultores. Así mismo, el área de cultivos transgénicos sobrepasó los 100 millones de hectáreas en 2006. 
El Servicio Internacional para la Adquisición de Aplicaciones Agrobiotecnológicas, ISAAA ${ }^{1}$, estima que para 2015, más de 20 millones de agricultores estarán sembrando unos 200 millones de hectáreas de cultivos transgénicos en unos 40 países. Hoy día, los países en vías de desarrollo representan el 40\% del área global de cultivos transgénicos. En el continente americano, además de Estados Unidos, Argentina y Brasil se encuentran entre los grandes productores del mundo. Recientemente Paraguay, México y Honduras se han incorporado al grupo de países productores.

A pesar de la expansión de los transgénicos, este tipo de biotecnología de plantas y la comercialización de productos y semillas transgénicas a nivel mundial, han generado debates agitados y controversia que no parecen tener fin, ni parece que se pueda alcanzar pronto un consenso general. Según sus defensores, los transgénicos representan una oportunidad para los productores por cuanto ofrecen soluciones en el control de plagas y malezas, así como la posibilidad de mejorar la calidad nutricional de los alimentos. Los detractores de la biotecnología agrícola, en cambio, arguyen riesgos potenciales a la salud humana, el medio ambiente y la biodiversidad. En muchos casos, la intención no es sólo regular el uso sino prohibirlo. En Nicaragua se ha propuesto la conformación de "zonas libres de transgénicos". ${ }^{2}$ Además, se ha informado en los medios de comunicación sobre la presencia de soya y arroz transgénico en el país.

Motivado por esta situación, el Centro de Biología Molecular de la UCA, a través de un muestreo al azar, se propuso investigar la presencia de material transgénico en arroz, soya y maíz importados y disponibles en los principales puestos de venta del país. Aquí presentamos los resultados del trabajo y reportamos que, en el período comprendido en este estudio, no se detectaron semillas transgénicas en Nicaragua.

\section{Materiales y metodología}

La metodología utilizada consistió de cuatro etapas: muestreo, pruebas inmunológicas, extracción de $\mathrm{ADN}$ de semillas y detección de $\mathrm{ADN}$ transgénico por medio de la reacción en cadena de la polimerasa (PCR). En la Ilustración 1 se presenta un esquema del procedimiento. 
Detección de material transgénico mediante ensayos inmunológicos

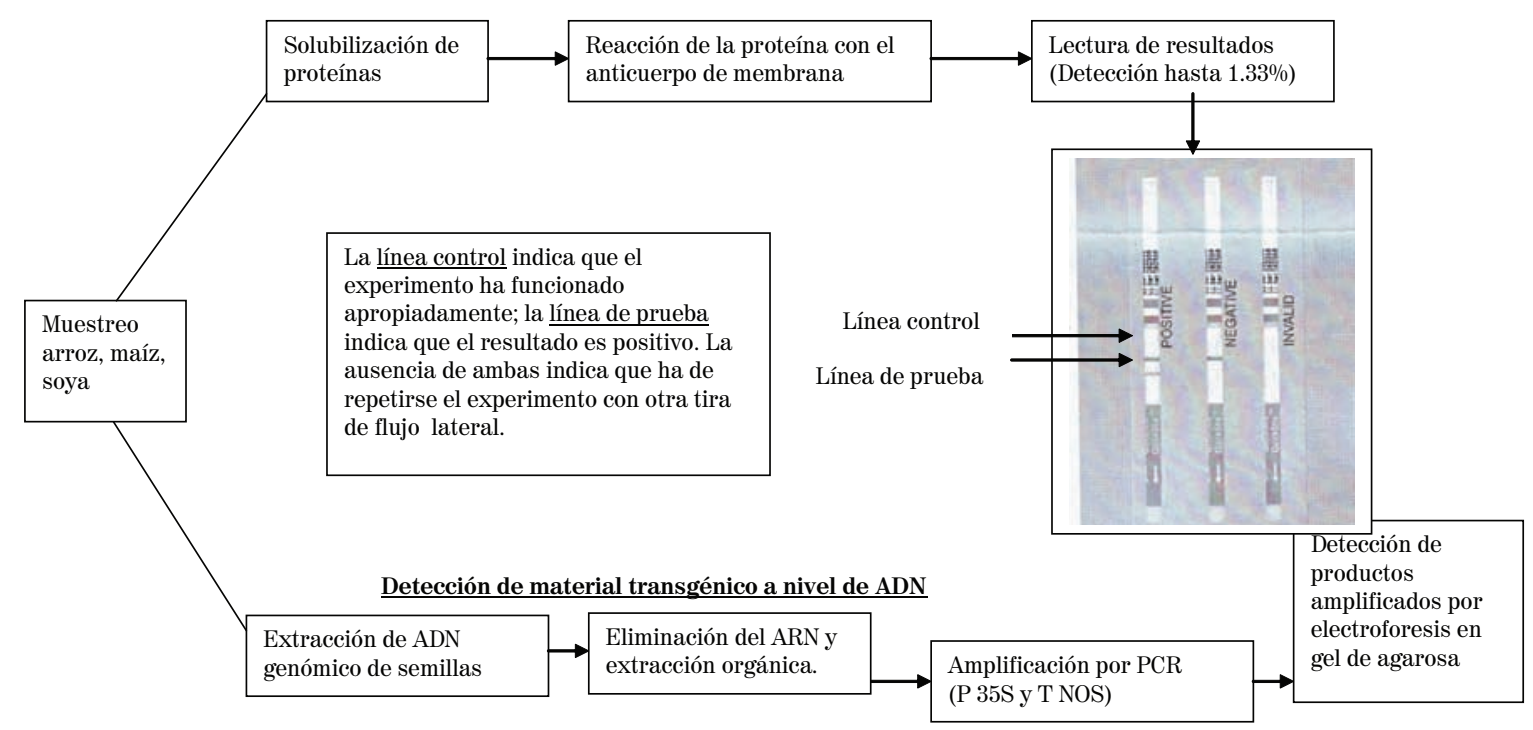

Ilustración 1: Métodos inmunológicos y moleculares para detección de transgénicos

\subsection{Muestreo}

En el Programa de Diagnóstico Molecular del Centro de Biología Molecular se recibió un total de 80 muestras de arroz (Oryza sativa) de varios tipos: arroz oro, granza, puntilla y blanqueado. La mayoría consistió de $1 \mathrm{~kg}$ de muestras de arroz importado de EEUU con fines comerciales como alimento humano y animal, enviado a nuestro laboratorio por las empresas importadoras. A todas estas muestras se les realizó análisis por PCR y pruebas inmunológicas de proteínas usando tiras de flujo lateral. Para fines de este estudio se seleccionó al azar un total de 20 muestras.

Así mismo, se recogieron al azar 20 muestras de maíz (Zea mays) en los principales mercados de Managua (Oriental, Mayoreo y Roberto Huembes; ver Cuadro 1). En estos mismos lugares se colectó un total de 13 muestras de soya (Glycine max), además de muestras procedentes del mercado de Masaya. No se pudo obtener más muestras de soya debido a una aparente escasez del producto en las fechas de colecta (octubre 2007). Igualmente, no se encontró soya en ninguno de los puestos de venta visitados de León y Ocotal en el norte del país. 
Cuadro 1: Muestreo de maíz en mercados y supermercados de Nicaragua

\begin{tabular}{|l|l|l|l|}
\hline $\begin{array}{l}\text { No de } \\
\text { muestra }\end{array}$ & Tipo de muestra & Sitio de muestreo & Procedencia \\
\hline 1 & Maiz blanco & M Oriental & Nicaragua \\
\hline 2 & Maiz blanco & M Oriental & Nicaragua \\
\hline 3 & Maiz amarillo & M Oriental & Nicaragua \\
\hline 4 & Maiz pujagua & M Oriental & Nicaragua \\
\hline 5 & Maiz blanco & M. R. Huembes & Nicaragua \\
\hline 6 & Maiz blanco & M. R. Huembes & Nicaragua \\
\hline 7 & Maiz blanco & M. Mayoreo & Nicaragua \\
\hline 8 & Maiz blanco & M. Mayoreo & Nicaragua \\
\hline 9 & Maiz para palomitas & M. Mayoreo & Nicaragua \\
\hline 10 & Maiz para palomitas & Super Palí & Estados Unidos \\
\hline 11 & Maiz para palomitas & Super La Colonia & Estados Unidos \\
\hline 12 & Maíz para palomitas & Super La Unión & Nicaragua \\
\hline 13 & Harina de maíz & Super La Unión (del Comal) & El Salvador \\
\hline 14 & Harina de maíz & Super La Unión (Sabemás) & Costa Rica \\
\hline 15 & Harina de maíz & Super La Unión (Maseca) & México \\
\hline 16 & Harina de maíz & Super La Unión (Goya) & Estados Unidos \\
\hline 17 & Maizena Sabemás & Super La Unión (Costa Rica) & Costa Rica \\
\hline 18 & Maizena & Super La Unión (Nicaragua) & Centroamérica \\
\hline 19 & Elote crudo-Rubenia & Super La Colonia/Rubenia & Nicaragua \\
\hline 20 & Elote crudo-Rubenia & Super La Colonia/ Rubenia & Costa Rica \\
\hline
\end{tabular}

\subsection{Pruebas inmunológicas}

Para las pruebas inmunológicas con lisado de proteínas se utilizaron varios paquetes comerciales de detección que usan tiras de flujo lateral. Para arroz transgénico se utilizó el paquete Liberty Link Rice que detecta la proteína Fosfinotricina-N-Acetil-Transferasa (Phosphinothricine-N-Acetil Transferase, PAT/bar en arroz, mientras el Round up Ready Soybean Kit se usó para detectar la presencia de la proteína PAT/bar y que le permite tolerancia al glufosinato en soya transgénica.

El equipo de investigación siguió estrictamente las instrucciones de la compañía biotecnológica comercializadora, pero señalamos aquí algunos pasos críticos. Las muestras de semillas de arroz o soya se muelen en una licuadora de laboratorio específica para este propósito (WARING comercial) hasta obtener un polvo fino. Luego se toma una pequeña cantidad que debe ser homogénea y se resuspende en un tampón de extracción que solubiliza las proteínas. A continuación, la tira, que tiene una almohadilla absorbente es introducida en la muestra con el tampón. La muestra viaja a través de la membrana de la tira que está equipada con anticuerpos específicos que se unen a la proteína PAT/bar, en caso de que 
ésta se encuentre en la muestra. La reacción entre el anticuerpo específico y la proteína, es observada al formarse las bandas de color rosado, una de prueba y la banda control que indica que la prueba se ha realizado con éxito. La aparición de sólo una banda (la banda control) indica un resultado negativo, mientras que la aparición de dos bandas indica un resultado positivo. De no aparecer ninguna banda, la prueba no tendría validez.

\subsection{Método de extracción de ADN de semillas}

Varios métodos desarrollados por Ahmadikhah (2005), Thangjam et al. (2003), Ren et al. (2006), así como en el manual del laboratorio de referencia de la Comisión Europea ${ }^{4}$ (2006), fueron usados para establecer un protocolo propio de extracción de ADN de las distintas especies de semillas (arroz, soya y maíz).

Las semillas se molieron en una licuadora de laboratorio (WARING comercial) hasta obtener un polvo fino que fue homogenizado y del cual se pesó 40mg separados individualmente en tubos Eppendorf de 1.5ml. Luego se agregó 700 $\mu$ l del tampón de extracción (100mM Tris-HCl pH: $8,50 \mathrm{mM}$ EDTA pH: 8, $500 \mathrm{mM} \mathrm{NaCl}$ ) al cual se agregó $7 \mu \mathrm{l}$ de $\beta$ - Mercaptoethanol, $50 \mu \mathrm{l}$ de SDS (Dodecilsulfato de sodio) al 20\% y $3 \mu$ l de proteínasa K, que fueron añadidos a la mezcla e incubados por 40 minutos a $65^{\circ} \mathrm{C}$ con mezclas por inversión intermitentes cada 5-10 min. Después se procedió a limpiar la muestra con una mezcla de cloroformo, fenol y alcohol isoamílico. Se centrifugó a 15,000 rpm por 5 minutos para separar dos fases. Se transfirió la fase superior a otro tubo Eppendorf y se precipitó con 5\% de acetato de sodio y dos tercios de isopropanol frío. Luego se centrifugó a 15,0000 rpm por 5 minutos y en la mayoría de las muestras se obtuvo un precipitado que se lavó con etanol al 70\% y se puso a secar al aire libre por $15 \mathrm{~min}$.

El ADN obtenido fue resuspendido en $50 \mu \mathrm{l}$ de agua desionizada y autoclavada, seguido de la eliminación del ARN con ARNasa A $(4 \mathrm{mg} / \mu \mathrm{l})$ a $65^{\circ} \mathrm{C}$ por $30 \mathrm{~min}$. La reacción para eliminar el ARN se terminó añadiendo un volumen de mezcla de fenol/cloroformo/alcohol isoamílico. El sobrenadante se trasladó a un tubo nuevo y después de obtenido el precipitado se lavó dos veces, primero con etanol al 70\% y luego con etanol al 95\%. El ADN fue rehidratado con agua destilada y autoclavada y se dejó por una hora a $65^{\circ} \mathrm{C}$. El chequeo del ADN se hizo a través de electroforesis en geles de agarosa al 0.8\% teñido con bromuro de etidio y visualizado a través de un transiluminador de rayos ultravioleta (UV).

\subsection{Reacción en cadena de la polimerasa (PCR)}

Las amplificaciones por PCR se efectuaron en un termociclador (Applied Biosystems) con un volumen total de mezcla de reacción de $50 \mu \mathrm{l}$ que contiene $1 \mathrm{x}$ PCR buffer, $0.5 \mathrm{mM} \mathrm{MgCl}^{2}$, $0.2 \mathrm{mM}$ dNTPs (deoxirribonucleótidos), $0.54 \mathrm{mM}$ de cada primer (sentido y antisentido) y 2 unidades de Hot-start Taq polimerasa (Finnzymes), y finalmente, $2 \mu$ l de ADN de cada muestra estudiada. El programa de reacción de PCR consistió de un ciclo de 3 min a $94^{\circ} \mathrm{C}$; 35 ciclos de $30 \mathrm{seg}$ a $94^{\circ} \mathrm{C}, 30 \mathrm{seg}$ a $55^{\circ} \mathrm{C}$ y $55 \mathrm{seg}$ a $72^{\circ} \mathrm{C}$, y adicionalmente, se sometió a una extensión final de 7 min a $72^{\circ} \mathrm{C}$. 
Dos análisis por PCR se realizaron en este estudio. Por un lado, se estudió un fragmento de 176 pb amplificado de la secuencia terminadora de NOS (Nopalin sintasa de Arabidopsis thaliana) usando un set de iniciadores (primers) con sentido (5'-GAATCCTGTTGCCGGTCTTG-3') y antisentido (5'-TTATCCTAGTTTGCGCGCGCTA-3'). Por otra parte, se amplificó un fragmento de $195 \mathrm{pb}$ del promotor del virus del mosaico del tabaco $35 \mathrm{~S}$ usando un set de iniciadores con sentido (5'- GCTCCTACAAATGCCATCA-3') y antisentido (5'-GATAGTGGGATTGTTGTCA-3').

Todos los iniciadores fueron sintetizados por la compañía norteamericana Integrated DNA Technologies, INC. El ADN comercial del plásmido pBI121 fue usado como control positivo ya que contiene las secuencias del promotor 35S y del terminador NOS. Como control negativo en la reacción se utilizó agua pura tratada con ADNasas y ARNasas. Los fragmentos amplificados fueron visualizados después de correr el gel de agarosa al 2\% y a 100 voltios por $30 \mathrm{~min}$.

\section{Resultados}

\subsection{Pruebas inmunológicas negativas}

Todas las pruebas inmunológicas realizadas a las muestras de soya y arroz dieron resultados negativos, lo que indica que los materiales evaluados no contenían trazas de proteínas transgénicas o que, de contenerlas, éstas estarían representadas en un porcentaje menor al 1.33\% de material transgénico -según el alcance de detección del método. Los resultados se presentan en las Ilustraciones 2 y 3. Todas las tiras muestran reacción negativa del anticuerpo con las proteínas del lisado de las semillas, mientras que sólo los controles positivos de muestras de transgénicos conocidos muestran bandas positivas.

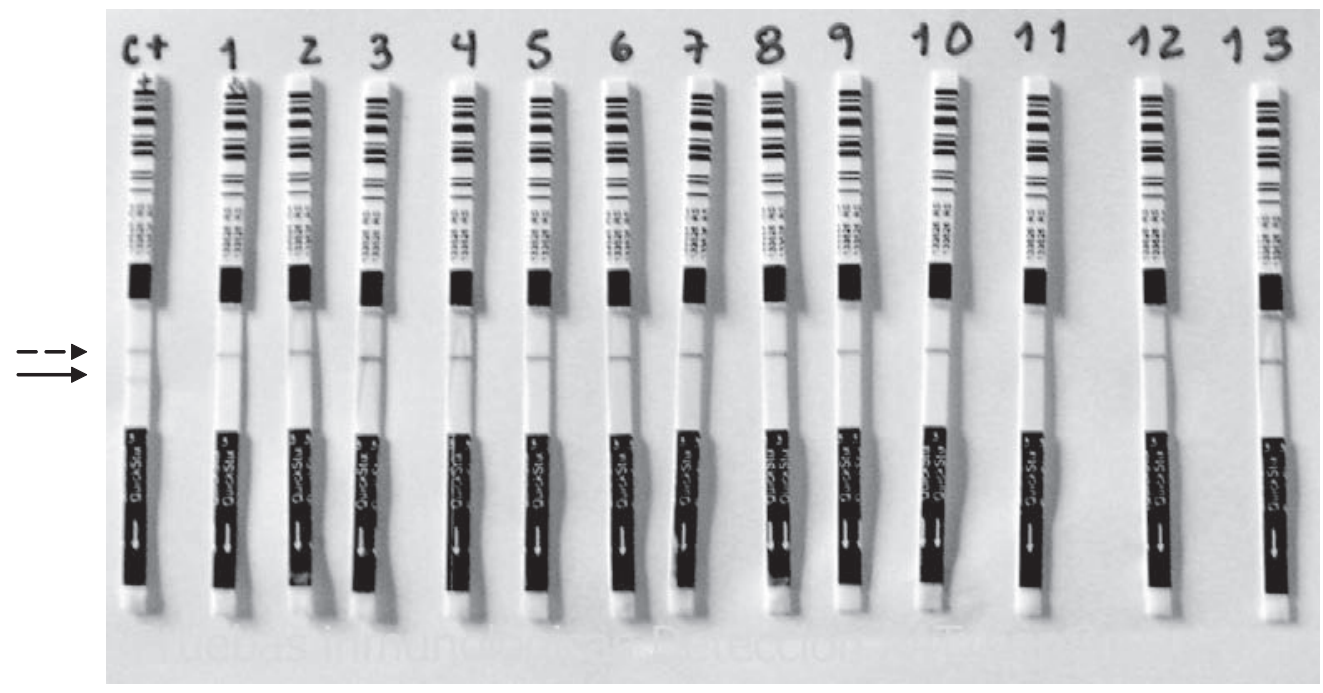

Ilustración 2. Resultados de pruebas de proteínas para 13 muestras de soya y un control positivo $(\mathrm{C}+)$. Todas las pruebas dieron resultados negativos.

La flecha discontinua señala la línea de control del experimento.

La flecha continua señala la línea de prueba (Test line) e indica un resultado positivo. 
La flecha discontinua señala la línea control del experimento
La flecha continua señala la línea de prueba (test line) e indica un resultado positivo

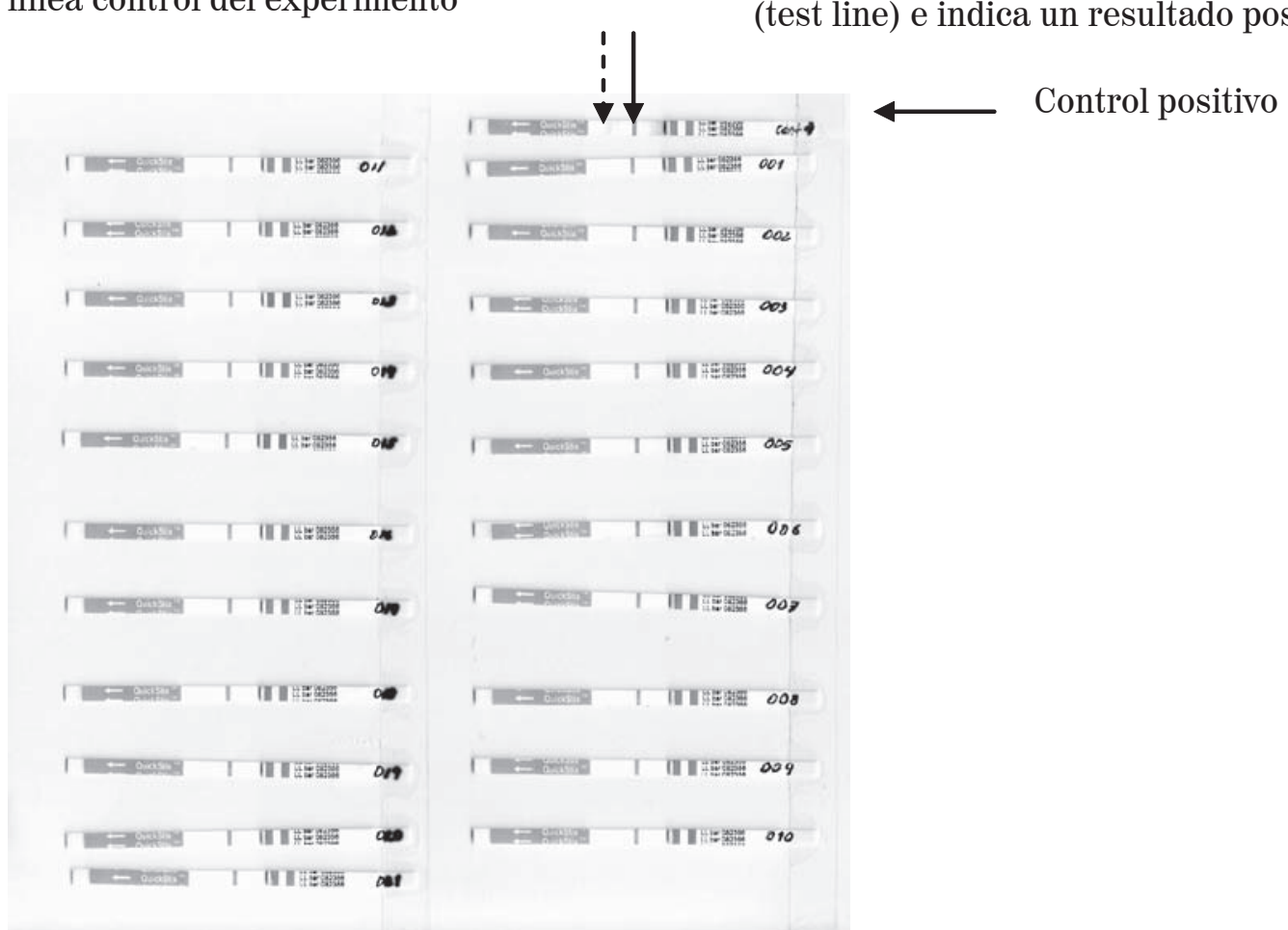

Ilustración 3. Resultados negativos de la prueba de proteínas para las primeras 20 muestras de arroz.

La presencia de la línea control y la ausencia de la línea de prueba de las tiras de flujo lateral indican que las tiras han funcionado apropiadamente y que los resultados son negativos.

\subsection{Amplificación negativa de ADN transgénico}

Todas las muestras estudiadas mostraron falta de amplificación de fragmentos para las regiones del promotor 35S y el terminador NOS. En las fotografías presentadas como ilustraciones en este trabajo se puede observar que las muestras no presentan bandas de amplificación de ADN transgénico, ya sea de 195 pb del 35 S o de 176 pb del NOS. Se presentan los resultados de soya (Ilustración 4), maíz (Ilustraciones 5 y 6 ) y de arroz (Ilustraciones 7 y 8). Se tuvo el cuidado de verificar la buena calidad de todos los ADN utilizados. En la Ilustración 9 se muestran resultados del ADN extraído de arroz. Similares resultados se obtuvieron para maíz y soya. Como control positivo de amplificación se utilizó un vector comercial que contiene tanto el gen del promotor como del terminador. Como control negativo se utilizó agua pura sin trazas de ADN. Como se observa en las fotografías, todas las reacciones fueron exitosas logrando amplificar el ADN de control positivo y sin amplificar nada en la muestra de control negativo (agua), indicando que no hubo amplificación por falsos positivos. 


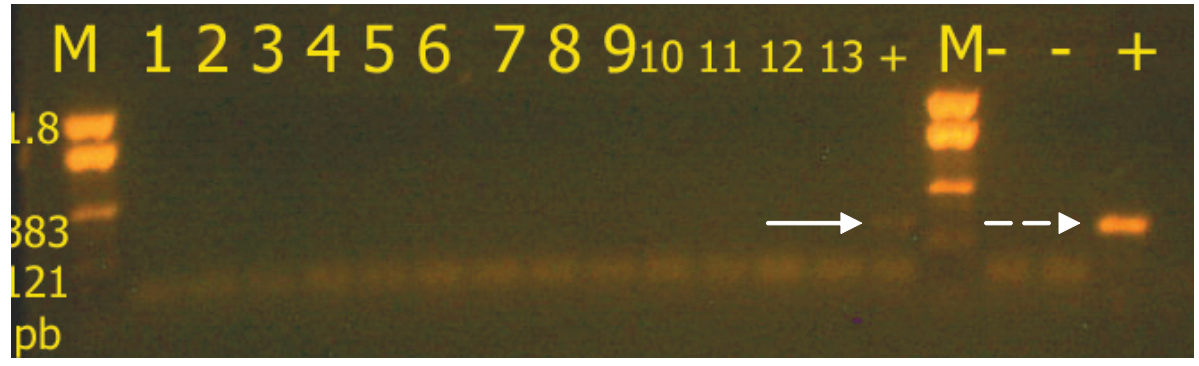

Ilustración 4. Resultados de la amplificación por PCR del promotor 35S para 13 muestras de ADN de soya y un control positivo.

Como se puede observar, sólo los controles positivos presentan una banda de 195 pares de bases (pb), todas las muestras restantes son negativas.

La flecha continua señala el control positivo de ADN de soya transgénica.

La flecha discontinua señala el control positivo del ADN del plásmido pBI121.

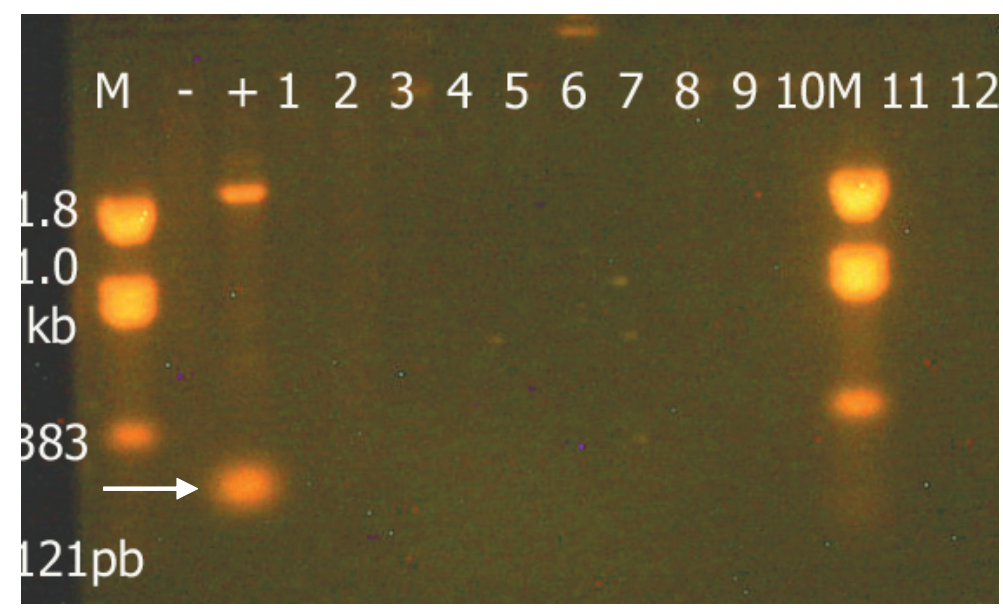

Ilustración 5. Resultados de la amplificación del promotor 35S en muestras de ADN de maíz.

Se puede observar una sola banda de $195 \mathrm{pb}$ para el control positivo, las muestras restantes son negativas.

La flecha señala la banda de 195pb del control positivo (plásmido pBI121) correspondiente al producto amplificado del promotor $35 \mathrm{~S}$. 


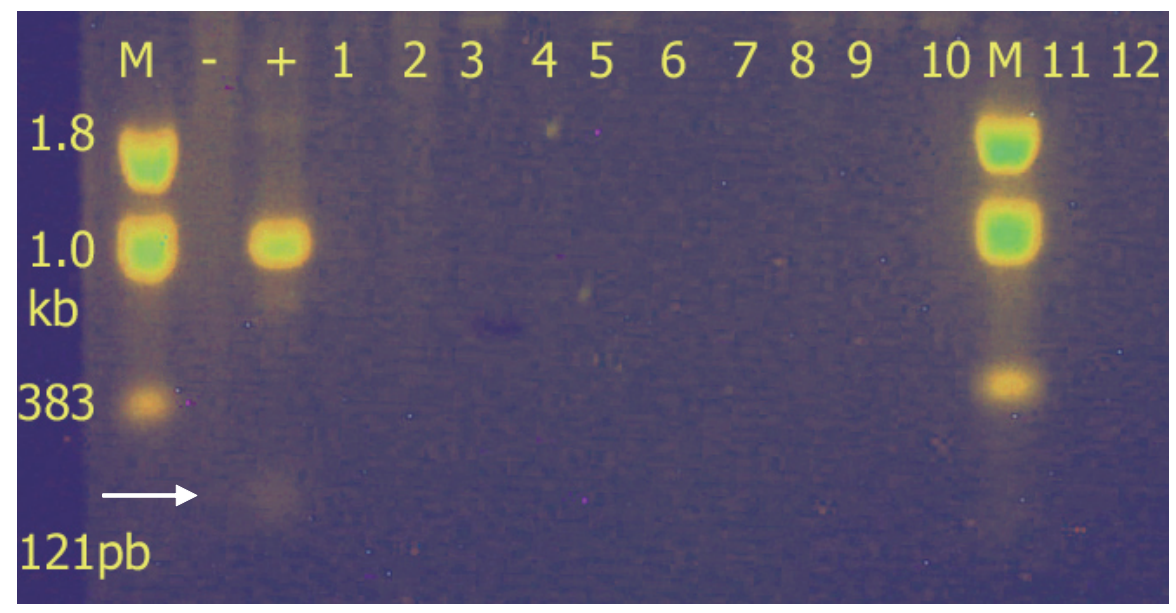

Ilustración 6. Resultados de la amplificación del terminador NOS en muestras de ADN de maíz.

Se puede observar una sola banda de $176 \mathrm{pb}$ para el control positivo, las muestras restantes son negativas.

La flecha señala la banda de 176pb del control positivo (plásmido pBI121) correspondiente al producto amplificado del terminador NOS. El control positivo generalmente muestra una banda superior de alrededor de $1 \mathrm{~Kb}$ de carácter inespecífico.

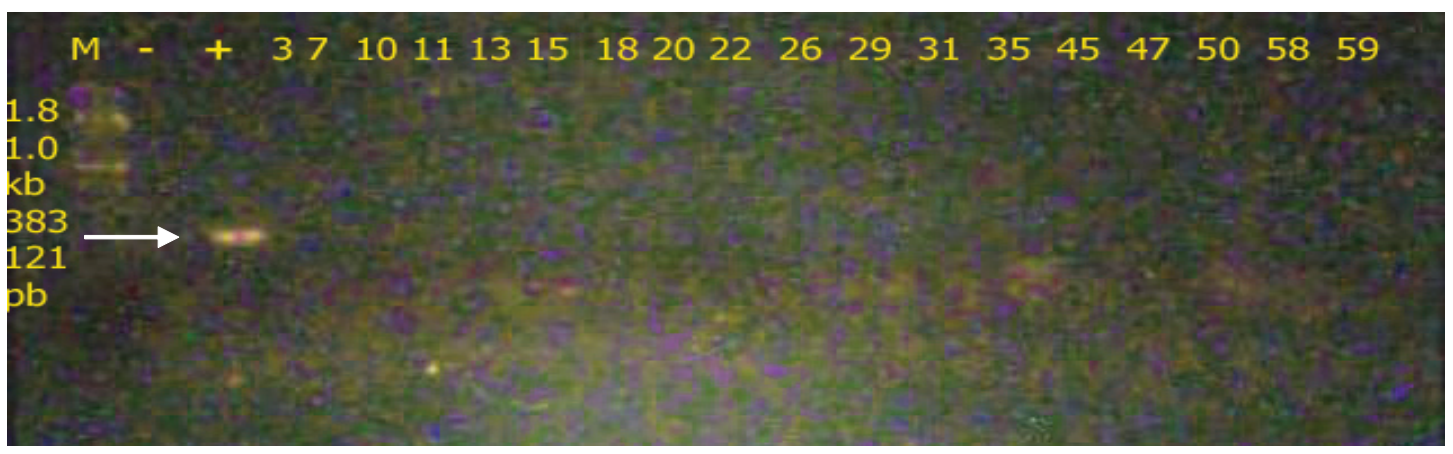

Ilustración 7. Resultados de la amplificación del promotor 35S en muestras de ADN de arroz.

Se puede observar una sola banda de 195 pb para el control positivo, las muestras restantes son negativas.

La flecha señala la banda de 195 pb del control positivo (plásmido pBI121) correspondiente al producto amplificado del promotor $35 \mathrm{~S}$ 


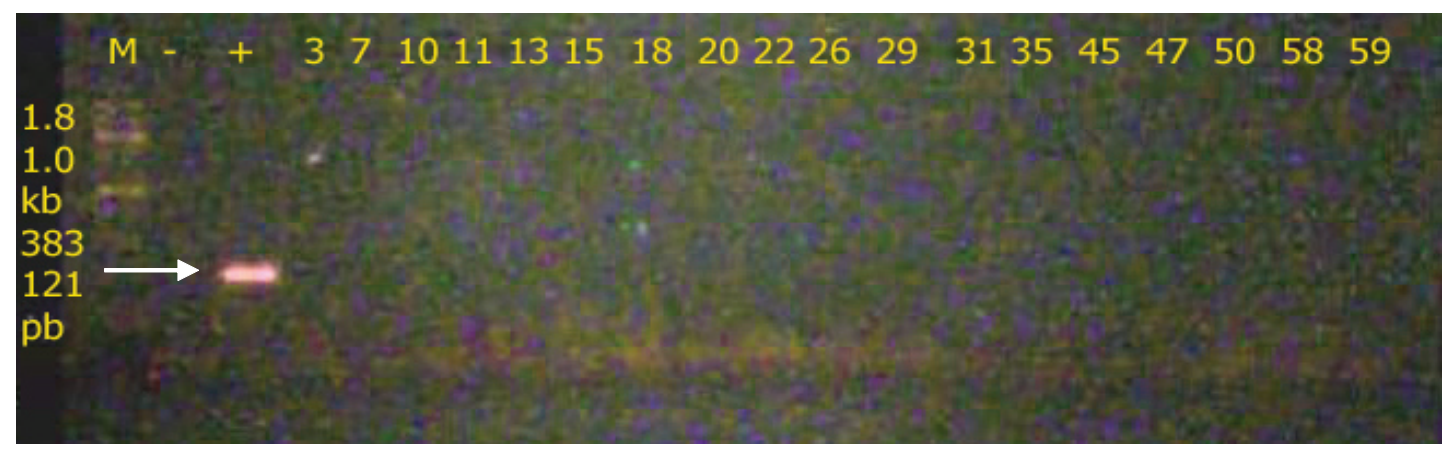

Ilustración 8. Resultados de la amplificación del terminador NOS en muestras de ADN de arroz.

Se puede observar una sola banda de $176 \mathrm{pb}$ para el control positivo, las muestras restantes son negativas.

La flecha señala la banda de 176pb del control positivo (plásmido pBI121) correspondiente al producto amplificado del terminador NOS.

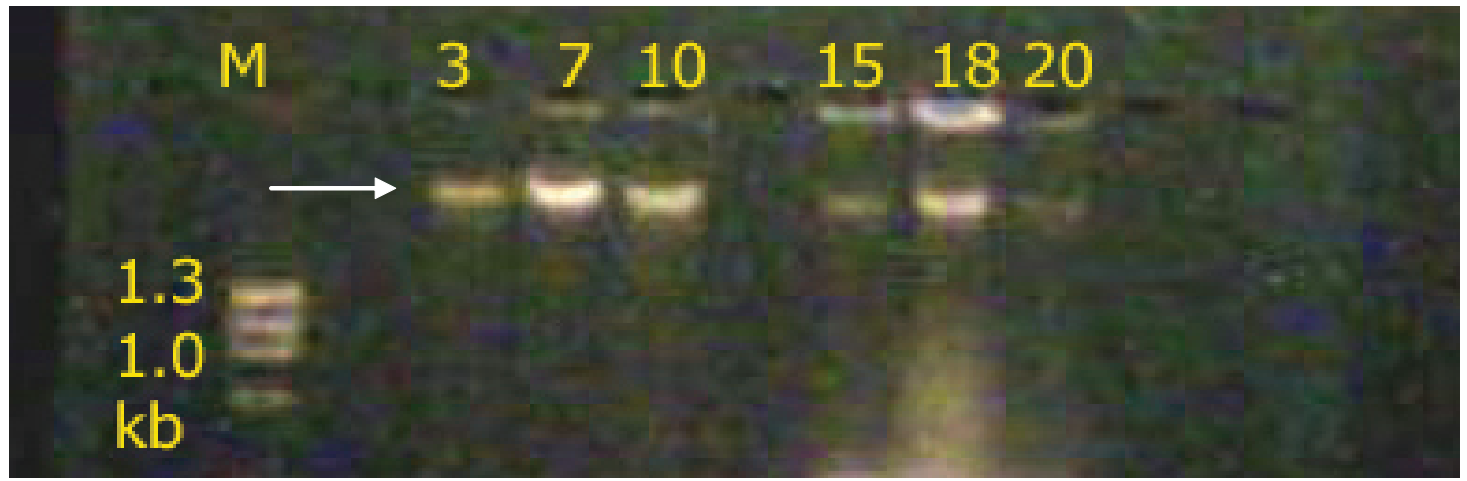

Ilustración 9. Se muestra el resultado de la extracción de ADN de 6 muestras de arroz utilizando el protocolo de extracción de ADN genómico de semillas adaptado en el Centro de Biología Molecular.

Las bandas indicadas por la flecha indican que el ADN extraído es de buena calidad. M: marcador de peso molecular, ADN de PhiX174 digerido con Hae III.

\section{Discusión}

En este estudio se usaron dos métodos comúnmente utilizados en la detección de rutina en laboratorios de diagnóstico molecular. Se requiere usar métodos rápidos y sensibles que puedan auxiliar en muestreos de rutina en importaciones de semillas. Las pruebas inmunológicas en lisado de proteínas que usan tiras de flujo lateral son de carácter cualitativo, no cuantitativo, y normalmente se emplean en pruebas de campo en EEUU y Europa. Existen diversos paquetes comerciales de detección específica de transgénicos 
conocidos, así como pruebas más generales que detectan colectivamente varios tipos de transgénicos (Stave, 2002).

Además del uso de pruebas inmunológicas entre las que se incluyen los métodos de ELISA, se acostumbra el uso adicional de tecnología de PCR como métodos auxiliares de confirmación de resultados. Para este propósito, en nuestro Centro se procura identificar tanto secuencias del promotor como del terminador, dos secuencias de uso obligatorio en la construcción de transgénicos de plantas. Se ha estimado que el grado de confianza de esta técnica es de $99.5 \%$, por lo que se considera que de cada 100 granos pertenecientes a estas muestras, al menos 99.5 no sean transgénicos.

A través de la PCR se trata de detectar directamente la construcción del transgén insertado en el ADN de la planta. En conjunto con un gen particular de interés, las regiones NOS y $35 \mathrm{~S}$ son utilizadas comúnmente en ingeniería genética y están presentes en la gran mayoría de plantas y alimentos transgénicos comercialmente disponibles hoy día. Aunque la detección de estas dos regiones no brinda información sobre los tipos de transgénicos específicos, en el caso de detectarlas como positivas, el investigador puede avanzar en su indagación con una segunda reacción más específica para los transgénicos sospechados.

Este abordaje es relativamente simple en el caso de arroz transgénico porque apenas hay tres tipos de transgénicos comercialmente disponibles: LLRICE06, LLRICE62 y LLRICE601. Estos tipos de arroz contienen todos el gen bar que codifica la proteína FosfinotricinaN-Acetil-Transferasa (PAT) que le permite resistencia al glufosinato, un herbicida de uso común. Además, todos utilizan el promotor $35 \mathrm{~S}$, por lo que se puede utilizar esta región en la detección del transgénico por PCR. La detección inmunológica de las proteínas transgénicas también se facilita con el uso de una sola prueba para detectar los tres tipos de arroz transgénico.

Para el caso de la soya transgénica resistente a herbicida se procura la detección de PAT y además la expresión del gen epsps que codifica la proteína 5-Enolpiruvilshikimato3 -fostato Sintasa, que garantiza tolerancia al herbicida glifosato (RoundUp). Existen al menos nueve tipos de soya transgénica resistentes a herbicidas de tres compañías. Éstos han sido aprobados para comercialización y consumo humano y animal en más de 15 países, incluyendo Argentina, México y EEUU, países con los cuales Nicaragua tiene amplias relaciones comerciales.

En esta investigación no se encontraron trazas de material transgénico en maíz a juzgar por los resultados de no amplificación por PCR. Esto se hizo con las secuencias del promotor 35S y del terminador NOS. Este método es el más recomendado para muestreo rápido en maíz, dada la gran diversidad de tipos de transgénicos. Éstos incluyen más de 40 tipos (eventos) con características de resistencia a varias clases de herbicidas, así como con características de insecticidas (Bt). Por otra parte, sería conveniente también incorporar el uso de algunos paquetes de detección de proteínas por métodos inmunológicos para detección de un amplio rango de transgénicos en maíz. Recientemente, nuestro laboratorio ha adquirido este tipo de detección, que deberá estar listo muy pronto. 
Además de utilizar métodos cualitativos, conviene implementar métodos cuantitativos que indaguen sobre la cantidad exacta de ADN encontrado en las muestras estudiadas. El método de ELISA y el de PCR de Tiempo Real (RT-PCR) son en la actualidad las dos técnicas principales de diagnóstico cuantitativo (García et al., 2004). También la técnica de microarreglos se ha comenzado a utilizar, aunque con menos frecuencia (Leimanis et al., 2006; Bordoni et al., 2005). El método de RT-PCR viene implementándose cada vez más en los laboratorios de alta tecnología por su gran especificidad y sensibilidad alcanzando límites de detección de entre 0.01 y $0.1 \%$.

Estos métodos de cuantificación de trazas de transgénicos son los más recomendables cuando se requiere cumplir normas de restricción sobre el uso de transgénicos. Conviene enfatizar aquí que estas técnicas requieren de equipos y materiales más costosos, lo que hace que estos servicios sean menos solicitados en países en vías de desarrollo.

Los países de la Unión Europea han establecido normas de etiquetado para productos que contengan ingredientes de origen transgénico en proporción mayor al $0.9 \%$ y en otros casos del $2 \%$ y $3 \%$, aunque los críticos de los alimentos transgénicos han propuesto que el límite sea del $0.1 \%$. Muestras que contengan un porcentaje mayor serían consideradas como transgénicas y tendrían que etiquetarse como tales.

En Nicaragua no existen normas que prohíban el ingreso de alimentos y semillas transgénicas, por lo que la detección cualitativa de rutina a través de los métodos utilizados en este estudio es suficiente para que las autoridades fitosanitarias del país tengan conocimiento sobre la situación de las importaciones en este respecto. En el caso de que Nicaragua estableciera normas prohibitorias del uso e importación de semillas transgénicas, tendría que normarse también el etiquetado y establecerse límites permisibles de material transgénico.

En el cumplimiento de tales normas, las autoridades tendrían que analizar las importaciones de semillas y granos tanto por métodos cuantitativos como cualitativos. Del mismo modo, en el caso que las autoridades nicaragüenses aprobaran la siembra de semillas transgénicas, tendría que establecerse protocolos de siembra, y evaluar y monitorear la situación ambiental de las zonas autorizadas para la siembra. Un caso muy especial para Nicaragua sería el caso del maíz transgénico, por considerarse este país un centro de origen. Con el propósito de preservar su biodiversidad tendría que establecerse protocolos rigurosos y monitoreo continuo.

Por el momento, considerando los resultados de este trabajo de investigación sobre semillas de arroz, soya y maíz, concluimos que en el período comprendido en este estudio, no se detectaron semillas transgénicas en Nicaragua. 


\section{Notas}

$1 \mathrm{http}: / /$ www.isaaa.org/

2 "Alianza por una Nicaragua libre de Transgénicos". http://www.cisas.org.ni/APB-N

3 Denuncian venta de arroz transgénico. La Prensa, edición 14 de febrero, 2007. Disponible: http://www.laprensa.com.ni/ archivo/2007/febrero/14/noticias/ultimahora/173438.shtml

4 European Food Safety Authority Report. Statement of the Scientific Panel on Genetically Modified Organisms in response to the request of the European Commission on inadvertent presence of genetically modified rice LLRICE601. England. 2006. Disponible en: www.efsa.europea.eu/en//science/gmo/statements0/efsa_statements_gmo_LLrice601.html (Consultado el 30 de Julio de 2007)

\section{Referencias bibliográficas}

AHMADIKHAH, A. (2005). A New Mini-prep and Rapid DNA Extraction Method. Rusia. Biotechnology Department, Russian State Agricultural University, and Agricultural \& Natural Resources University, Gorgan Iran. Disponible en: http://www.wzw.tum.de/ gene-quantification/qpcr2005/pub/P01-Ahmadikhah-qPCR-2005.pdf (Consultado el 2 de agosto de 2007).

BORDONI, R.; GERMINI, A.; MEZZELANI, A.; MARCHELLI, R. \& DE BELLIS, G. (2005). “A microarray platform for parallel detection of five trangenic events in foods: a combined PCR ligation dtection reaction universal array method". En J. Agric Food Chem. 53:912.

GARCÍA, V.; CIFUENTES, A. \& GONZÁLEZ, R. (2004). "Detection of genetically modified organisms in food by DNA amplification techniques". En Crit Rev Food Sci Nutr. 44(6):425.

JAMES, C. (2007). Global State of commercial biotech/ GM Crops: 2006. International Service for the Acquisition of Agri-biotech Applications (ISAAA). Disponible en: http:// www.isaaa.org (Consultado el 10 de noviembre de 2007).

LEIMANIS, S.; HERNÁNDEZ, M.; FERNÁNDEZ, S.; BOYER, F.; BURNS, M. BRUDERER, S.; GLOUDEN, T.; HARRIS, N.; KAEPPELI, O.; PHILLIPP, P.; PLA, M.; PUIGDOMÈNECH, P.; VAITILINGOM, M.; BERTHEAU, Y. \& REMACLE, J. (2006). "A micro-array-based detection system for genetically modified food ingredients". En Plant Mol Biol. 61:123

REN, X.; ZHU, X.; WARNDORFF, M.; BUCHELLI, P. \& SHU, Q. (2006). "DNA Extraction and Fingerprinting of Commercial Rice Products”. En Food Research International Vol. 39, issue 4: 433-439.

STAVE, J.W. (2002). "Protein immunoassay methods for the detection of biotech crops: applications, limitations and practical considerations". En J AOAC Int; 85: 780.

THANGJAM, R.; MAIBAM, D. \& SHARMA, J. (2003). "A Simple and Rapid Method for Isolation of DNA from Imbibed Embryos of Parkia timoriana (DC.) Merr. for PCR Analysis”. En Food, Agriculture \& Environment Vol. 1 (3\&4): 36-38. 